Purdue University Purdue e-Pubs

\title{
Information-Seeking Behaviors of First-Semester Veterinary Students: A Preliminary Report
}

Sharon A. Weiner

Purdue University, sweiner@purdue.edu

Gretchen Stephens

Purdue University,gms@purdue.edu

Abdelfattah Y.M. Nour

Purdue University,nour@purdue.edu

Follow this and additional works at: http://docs.lib.purdue.edu/lib_fsdocs

Part of the Information Literacy Commons, and the Veterinary Medicine Commons

\section{Recommended Citation}

Weiner, Sharon A.; Stephens, Gretchen; and Nour, Abdelfattah Y.M., "Information-Seeking Behaviors of First-Semester Veterinary Students: A Preliminary Report" (2011). Libraries Faculty and Staff Scholarship and Research. Paper 84.

http://dx.doi.org/10.3138/jvme.38.1.21 
Information-Seeking Behaviors of First-Semester Veterinary Students: A Preliminary Report

\section{Authors:}

Sharon A. Weiner

Gretchen Stephens

Abdelfattah Y. M. Nour 


\section{ABSTRACT}

Although there is an increasing emphasis in veterinary education on the ability to find, use, and communicate information there are few studies on the information behaviors of veterinary students or professionals. Improved knowledge in this area will provide valuable information for course and curriculum planning and the design of information resources. This paper describes a survey of the information-seeking behaviors of first-semester veterinary students at Purdue University. A survey was administered as the first phase of a progressive semester-long assignment for an introductory course in mammalian physiology. The survey probed for understanding of the scientific literature and its use for course assignments and continuing learning.

The results of this survey showed that students beginning the program tended to use Google for coursework, although some also used the resources found through the Libraries' web site. On entering veterinary school, they became aware of specific information resources in veterinary medicine. They used a small number of accepted criteria to evaluate the quality of websites. This study confirms the findings of studies of information-seeking behaviors of undergraduate students. Further studies are needed to examine whether those behaviors change as students learn about specialized veterinary resources that are designed to address clinical needs as they progress through their training.

Key Words: Educational approaches for learning; E-learning; skills, Knowledge and professional attributes; Veterinary medical education; Veterinary educational challenges; Wikipedia; Educational approaches for learning 


\section{INTRODUCTION}

Recent reports on veterinary education identified skills related to finding and using information as skills that veterinary practitioners need to develop. ${ }^{1,2,3}$ Information is abundant, so "the problem now is discrimination: the ability to discriminate between spurious information, accurate but completely irrelevant information, and relevant information capable of application to solve a patient's problems." 4 Competency with these skills is commonly called "information literacy," that is, the ability to:

- "Determine the extent of information needed

- Access the needed information effectively and efficiently

- Evaluate information and its sources critically

- Incorporate selected information into one's knowledge base

- Use information effectively to accomplish a specific purpose

- Understand the economic, legal, and social issues surrounding the use of information, and access and use information ethically and legally."

These skills are associated with the ability to be lifelong learners. ${ }^{6}$

There is an extensive body of literature related to librarians as collaborators with academic faculty in teaching information literacy competency in colleges and universities. ${ }^{7-11}$ This is true for medical school education, as well. ${ }^{12}$ However, there are few articles that address veterinary information literacy or library instruction. ${ }^{13}$ There are even fewer studies of information-seeking skills or behaviors of veterinary students. ${ }^{14-17}$ The 1998 study by Pelzer, Wiese, and Leysen focused on determining the purposes for which students used the library facility, their use of electronic and print resources, their attendance at formal educational presentations by librarians, and their strategies for continuous learning. ${ }^{18}$ It is important to know how to find information about animal health information because it is a complex and 
time-consuming process. "In many cases, the small amount of relevant literature means that the searcher will use or share all the literature found, rather than focus on evaluating the validity of the articles to narrow the output further...Conference proceedings are very important in veterinary medicine. Many papers never transition from the conference presentation level to journal article publication." ${ }^{19}$

Some of the existing studies indicate concern about the information literacy competency of veterinary students and practitioners. One suggested that "a significant number of third-year veterinary students have difficultly answering applied questions about topics that are novel to them. This is a necessary and critical tool for the practicing veterinarian" ${ }^{20}$ In clinical situations, veterinarians generally do not conduct extensive literature searches unless they intend to submit a paper for publication. Veterinary students do not tend to perform required literature searches to help them develop treatment plans; instead, they perform them after they develop the plans. ${ }^{19}$

Problem-based learning (PBL) was introduced into medical curricula around forty years ago, and scholarly articles on the impact of PBL on library use and information-seeking behavior began to appear in $1992 .{ }^{21} \mathrm{~A}$ key tenet of PBL is the ability to find, integrate, and use information to address a specific clinical problem. PBL incorporates self-directed and deep learning. ${ }^{22}$ These skills are part of information literacy competency.

Veterinary education, too, incorporated PBL, or "case-based" learning. ${ }^{22}$ Librarians may have roles as facilitators of PBL case teams, consultants, or teachers of information resources and search strategies. ${ }^{23}$ A veterinary medical librarian first advocated for the need to integrate information literacy into problem-based veterinary curricula in $1998 .^{24}$ In that same year, librarians at Iowa State University compared the results of a survey on library use and information-seeking behavior of veterinary students with data obtained in a similar survey conducted ten years earlier. They reported a major increase in the use of computerized indexes and other electronic resources. The highest use of those resources was by a 
group of students selected to learn through a problem-based method of instruction. ${ }^{18}$ In more recent years, veterinary librarians reported strategies they used to help students understand why a literature search is an important part of PBL. ${ }^{25}$ The University College Dublin reported on a case study that examined how PBL impacted the information-seeking behavior and information literacy of veterinary students in their school. Introducing PBL increased the students' need to have information skills. As a result, they visited the library earlier, improved their understanding of how to use resources, increased their discernment regarding information, and improved their ability to integrate information effectively. ${ }^{26}$

Clearly, there is a need for additional data to better understand how veterinary students obtain, use, and evaluate information for clinical purposes and for the education of lay people; for use in basic courses and for research. This will help with the planning of educational strategies that can address the information literacy concerns that may emerge. These questions led to the development of a survey to provide baseline data to understand the experiences of beginning veterinary students. This paper reports on the results of such a survey of first-semester students in the School of Veterinary Medicine at Purdue University.

\section{METHODS}

The Purdue University Institutional Review Board for use of human subjects approved this research project.

This survey was conducted as the first phase of a progressive semester-long assignment. A paper on the assignment itself is forthcoming. ${ }^{27}$ The purpose of the survey was to determine what resources first-semester veterinary students used to gather information for papers and projects related to their academic work. The intent was for the data to provide a baseline for understanding the information- 
seeking behaviors of these students. These data will help in developing course content and improving the delivery of the curriculum. The survey included questions relating to student demographics (age, gender, educational background) to identify any relationships between their background and their use of and knowledge about information resources.

The authors developed a twenty-one-item survey (see Appendix I) with open-ended and multiple choice questions. The survey questions that are related to information resources are similar to questions in the 1998 Iowa State survey used by Pelzer, Wiese, and Leysen. ${ }^{18}$ Drawing on earlier research, the authors developed questions intended to determine usage of newer resources such as Wikipedia and Google ${ }^{28}$ It included questions about attendance at presentations given by a librarian and about consultation with a librarian on using information resources. The basis for these questions is Standard 9.5 of the Accreditation Policies and Procedures of the American Veterinary Medical Association Council on Education, which indicates that a veterinary college library "shall have access to the human and physical resources necessary for development of instructional materials." ${ }^{29}$ This standard implies that librarians participate in the education of the students. At Purdue, this is fulfilled through the veterinary medical librarian, who is a guest lecturer for the "Applications and Integration" problem-based learning course. She teaches the students how to search for key information resources in veterinary medicine and prepares instructional materials to guide the students (http://www.lib.purdue.edu/vetmed/). They can consult with her when they have difficulty finding materials for their learning issues or course projects.

The survey included a question on veterinary resources for lay people because veterinarians need to provide information that is authoritative and understandable to lay people and animal owners. ${ }^{20}$ It included questions that asked the students why they would recommend the sites they listed because veterinarians need to be discriminating about information that they find. ${ }^{4}$ 
The course professor sent an email with a link to the survey to all students enrolled in the Systemic Mammalian Physiology BMS 81100 course in the Department of Basic Medical Sciences, Purdue University School of Veterinary Medicine, in Fall 2009. He required the students to complete the survey and gave course credit to students for completing it. Students responded to the survey between September 28 and October 31, 2009. All seventy students in the course responded to the survey; 69 completed it for a response rate of $98.6 \%$. The responses from the one survey that was begun, but not completed, were included in the results reported in this paper.

\section{RESULTS}

Demographics.

The majority of the respondents $(79 \%, n=55)$ were aged $22-26$. Thirteen percent $(n=9)$ of the respondents were under age 22 and $9 \%(n=6)$ were aged 26-35. None of the respondents were above 35 years of age. Eighty-one percent $(n=57)$ of the respondents were female. The majority $(94 \%, n=66)$ were born in the U.S. while the remaining $6 \%(n=4)$ were born in China, Japan, Poland, or South Korea. The college from which the largest number of respondents graduated most recently was Purdue University $(31 \%, n=22)$. Sixty-nine percent $(n=48)$ of the respondents graduated from other schools such as Ball State University; Indiana University-Purdue University Indianapolis (IUPUI); Delaware Valley College; Indiana University-Purdue University Fort Wayne (IPFW); Murray State University; University of California, Davis; and others. Four respondents entered veterinary school before completing their bachelor's degree.

\section{Library Experiences.}

Survey question \#6 asked how many presentations the student attended during college or at Purdue that were given by a librarian on using information resources. Table 1a shows the distribution of 
respondents who had attended presentations by librarians during college or at Purdue. Table $1 \mathrm{~b}$ shows the distribution of students who had consulted with librarians during college. All of the respondents had attended presentations that were given by a librarian and most of them $(89 \%, \mathrm{n}=62)$ had attended from 2 5 presentations. This number includes two lectures which the veterinary medical librarian had given to the students in another course in the weeks before they took the survey. All of the respondents had consulted with a librarian at least once on using information during college or at Purdue. [insert Tables 1a and 1b] Use of Wikipedia, Google, and Libraries' Web Sites.

Beginning veterinary students reported their past use of resources for course projects. Sixty-nine percent of the respondents used Google or Google Scholar for all or most of their course projects. Fortysix percent of the respondents used libraries web sites for all or most of their course projects. Seventeen percent of the respondents used Wikipedia. These findings confirm the results of previous studies that show that students tend to favor Wikipedia and Google for coursework. ${ }^{22,30,31}$ However, usage of Wikipedia for course projects in this study was considerably less than in a recent multi-institution study of undergraduate students. In that study, $52 \%$ of respondents used Wikipedia always or frequently during the course-related research process. ${ }^{22}$

The authors found in a subsequent study that Wikipedia has few resources related to veterinary fields. This is why the course director gave a Wikipedia editing assignment with the objective to review what is currently available on an animal physiology topic, evaluate that information in light of available resources, and fill the gap by writing or rewriting an evidence-based entry for Wikipedia. ${ }^{21}$ Figure 1 shows the distribution of students according to use of Wikipedia for class projects.

[insert Figure 1]

Evaluation of Web Sites. 
The veterinary medical librarian gave a presentation in the Applications and Integration course and briefly discussed a few criteria for evaluating web sites. Those criteria were:

- Currency - When was site developed, when updated, do links work?

- Accuracy - Who wrote it and why, can you contact him?

- Authority / Reliability - What are the author(s)' credentials and qualifications?

- Objectivity / Purpose - What is site's purpose, audience, bias?

To assess the responses to the open-ended question, "What criteria do you use to evaluate the quality of web sites and other information related to veterinary medicine?" the authors compared the responses to the categories of criteria identified in a study of web site rating tools and articles. That study reported an emerging consensus on key criteria for evaluating health related web sites. ${ }^{32}$ Table 2 shows the criteria from the Kim paper and an additional criterion, verification of information on the web site in other sources, and the frequency of responses by the students for each. The students could cite more than one criterion so the total number of responses is 179 . About one-third $(34 \%, \mathrm{n}=61)$ of the student responses were the authority of the source, including reputation of the source, credibility, and trustworthiness. Twenty-two percent $(n=39)$ of the responses were the disclosure of authors, sponsors, and developers, which includes the identification of the purpose, nature, sources of support, authorship, and origin of the site. Sixteen percent $(n=29)$ of the responses were the currency of the information, including frequency of updating and maintenance of the site. From $0 \%(n=0)$ to $11 \%(n=19)$ of the responses were other criteria. [insert Table 2]

Strategies for Exhaustive Literature Searches.

To evaluate the open-ended responses to the question, "What strategies do you use to conduct an exhaustive search of the literature to find information related to veterinary medicine?" the authors adapted a document compiled by a health sciences librarian that provided strategies for conducting exhaustive searches of the health literature (see Appendix II). ${ }^{33}$ The number of steps in this rubric was 22. 
Employing all of the strategies would result in an exhaustive search. Sixty-five respondents (93\%) listed from zero to three steps. Five respondents (7\%) listed from four to six steps. Definition of Literature Review.

In response to the open-ended question, "What is a literature review?" $44 \%(\mathrm{n}=31)$ of the respondents included at least one of the following attributes of a literature review in their definitions: describing, summarizing, comparing, providing an overview, or assessing. Most of the remaining 56\% $(n=39)$ respondents admitted that they did not know the definition for "literature review;" or they confused the term with a book review (critique of a single publication) or with peer review (evaluation of a publication by a panel of experts).

Identifying Scholarly Articles.

Ninety percent $(\mathrm{n}=62)$ of the respondents indicated that, of the choices given, CAB Abstracts was the most comprehensive source for identifying scholarly articles in peer-reviewed journals on veterinary medicine topics. Ten percent $(n=7)$ of the respondents indicated that the most comprehensive sources were a veterinary professor, Wikipedia, or J.G. Cunningham's Textbook of Veterinary Physiology, $4^{\text {th }}$ edition (St. Louis: Saunders/Elsevier, 2007), the textbook for the course.

Authoritative online source for veterinary information other than Wikipedia or Merck Veterinary Manual.

The students were asked to "list an authoritative source online for veterinary information (other than Wikipedia and Merck Veterinary Manual)." Figure 2 shows the distribution of those responses. Forty-three percent of the respondents listed VIN and 41\% listed the AVMA web site. Sixteen percent listed other sources. See Appendix III for the complete list.

[insert Figure 2] 
Rationale for recommending the site.

This open-ended question asked the respondents for the reasons that they recommended the above sites. Seventy respondents cited 186 reasons. Of the total number of reasons cited, the largest percentage of reasons was that the site was trusted or credible (37\%); it was produced by veterinarians or veterinary professors (31\%); or that the information was kept up-to-date (27\%).

VIN, the Veterinary Information Network, is a web site that includes databases, message boards, conference rooms, continuing education courses, information for lay people, and online proceedings. VIN offers veterinarians, veterinary students, and veterinary personnel reference material and professional continuing education online courses. There are more than 200 consultants and editors in all aspects of basic veterinary medicine and specialty areas such as anesthesia/analgesia, cardiology, zoonoses, and public health. VIN claims on its web site to have "easy and fast access to the most complete, up-to-date database of veterinary information -- and the largest team of specialists dedicated to helping colleagues online" (http://www.vin.com/). It is a reputable source for veterinary medicine related information. Some of the students' comments about why they selected VIN as an authoritative online source for veterinary information were:

- "They have links to a lot of information from conference proceedings."

- "There are several aspects to the site including access to some journal articles. I have used this site because it contains study aids for veterinary students."

Examples of why the respondents selected the American Veterinary Medical Association (AVMA) site as an authoritative online source for veterinary information were:

- "It was created by the American Veterinary Medical Association and is a reliable, up-to-date source backed by a large number of veterinarians. It also provides links to many veterinary journals and also current news within the veterinary profession." 
- "The above site not only contains JAVMA, the Journal of the American Veterinary Association, which can be used for up-to-date information in the form of a journal, but also has numerous issues written about throughout the website about numerous veterinary issues."

Web-based sources for veterinary information for a lay person.

The students were asked to list a source online for veterinary information that they would recommend to a lay person interested in finding veterinary information. One way to evaluate web sites is to determine their objectivity: whether they "reside on a server of an organization having political, philosophical, commercial, or other agendas." 34 This might be indicated by the top-level domain name, such as .edu, .com, or .gov ${ }^{35}$ or the type of resource (reference book, magazine, Google, or Wikipedia). Table 3 shows the student responses by category. Thirty-six percent $(n=25)$ of the students recommended an organization $(. \operatorname{org}) ; 23 \%(\mathrm{n}=16)$ recommended a corporate site $(. \mathrm{com})$; and sixteen percent $(\mathrm{n}=11)$ recommended a reference book or veterinary magazine. Only six percent $(n=4)$ recommended Google; the same number recommended Wikipedia.

[Insert Table 3]

The students were asked why they would recommend that site. Table 4 summarizes their responses. The most common reasons students gave for recommending a website was that it contained basic information for the public, lay, or general users that was credible, reliable, or trusted $(37 \%, \mathrm{n}=49)$; it was easy to understand, read, use, or navigate $(20 \%, \mathrm{n}=26)$; it was produced by veterinarians or veterinary organizations $(15 \%, \mathrm{n}=19)$; or that it contained comprehensive, concise, up-to-date veterinary information $(15 \%, \mathrm{n}=19)$.

[Table 4]

\section{DISCUSSION}


Most of the respondents to the survey were age 22-26, placing them in the "millennial" generation. Millenials are people who were between the ages of 18-29 in 2010. They embrace digital technology and "outpace older Americans in virtually all types of internet and cell use."36 This implies that the respondents to the survey were comfortable with the use of the Web for information-seeking. Since most of the students graduated from colleges other than Purdue, it is not possible to make assumptions about the access they had to technology or instruction about library or veterinary information resources before they came to Purdue. However, the survey did explore the students' use of reference resources as undergraduates. The results of this survey indicate that these beginning veterinary students had used Google or Google Scholar most often to find information for their course projects in college. These same resources and new ones were used for assignments at Purdue. This supports Griffiths and Brophy's finding that "Students prefer to locate information or resources via a search engine above all other options, and Google is the search engine of choice."24

Almost half of the respondents used libraries' web sites to find information for all or most of their projects. The faculty and librarians could build on the acceptance of libraries' web sites by ensuring that the sites remain current and relevant to their specific needs. Academic library web sites provide a gateway to subscription databases, e-resources, books, journals, and guides to other types of resources to filter information and help students efficiently find scholarly resources for their work. Google searches often return unmanageable numbers of hits, many of which are irrelevant.

Wikipedia was the least-frequently used resource of the three. Since students tend to use Wikipedia at the initial stages of gathering information for projects, it is understandable that the resource would be less useful as students become more knowledgeable and specialized. Alternatively, Wikipedia could be a useful resource world-wide if its veterinary-related information is updated by members of the 
veterinary community. ${ }^{21}$ Many college students around the world are using Wikipedia in the absence of access to good library resources because it is accessible and free.

The students were able to identify some authoritative sources for veterinary information other than Wikipedia and Merck Veterinary Manual, which the professor had given them to start their searches (Wikipedia, Merck Veterinary Manual, CAB Abstracts, and VIN) [see survey question results in Appendix III]. Further study might explore how the students integrate these sources into their information search process and the preferred resources on which they draw.

The respondents used only a few of the established criteria to evaluate the quality of web sites and other information related to veterinary medicine. Future training could include discussion and exercises incorporating the full range of evaluation criteria that have been identified.

More than half of the respondents were not able to accurately define a "literature review." Almost all of the respondents did not understand that an "exhaustive search" requires multiple strategies (see Appendix II), citing three or fewer steps. These beginning veterinary students might have had limited exposure to the terms in their undergraduate curricula or early in veterinary school. If they become clinicians, it is unlikely that they would need to conduct exhaustive literature searches, while researchers would need to have this competency. The first-semester students learned about review articles, using the libraries' catalog and web site, searching for veterinary journal articles, and evaluating web resources during two presentations the veterinary medical librarian gave during the "Applications and Integrations" course in the Fall semester. In other first-year courses, students are required to look for information from a variety of sources including the Internet. However, students work in groups and individual assignments do not require extensive literature searches. The main thrust of these courses is not to conduct research, but to integrate information in anatomy, histology, physiology, pharmacology, immunology to solve clinical cases. Students generally find the answers for these assignments in one or 
two sources. The resource lists that the librarian prepared for each PBL case frequently included review articles [samples found at end of Cases \#2-\#8 at <http://www.lib.purdue.edu/vetmed/>]. The professor for this course encouraged the students to use this resource. Students had access to the guide, "Basics of Veterinary Literature" (<http://www.lib.purdue.edu/vetmed/>). The librarian developed this site at the request of course professors, but the students were not required to use it. A recent study found that online, in-person, and blended instruction are equally effective for retention of information literacy skills. Future instructional efforts could incorporate any of these methods. ${ }^{37}$

These first-year students were aware of some of the most important resources for veterinary practitioners. Almost all of the respondents knew that CAB Abstracts was the most comprehensive source, of the choices given, for identifying scholarly articles in peer-reviewed journals on veterinary topics. Most cited VIN or the American Veterinary Medical Association site as another authoritative web resource for veterinary information. One source that they did not mention was the International Veterinary Information Service (IVIS) called the "largest veterinary library on the Internet" (http://www.ivis.org/), and available free to members of the veterinary community if they register. Although the students knew about some of these resources, it is not clear from the survey to what extent the students used them. Further investigation could determine how the students use these resources in relation to Wikipedia, Google, and the Libraries web site.

There is evidence that as little as one two-hour training session improves medical student performance in literature searching in evidence-based medicine. ${ }^{38}$ This training should be the minimum incorporated into veterinary school curricula.

As a result of the findings in this survey, the course professor changed aspects of the course assignment and the veterinary medical librarian developed a handout. To strengthen their ability to find, use, and communicate information, students are required to investigate Wikipedia for animal physiology 
information, critique the available information, and identify gaps that can be researched. When students choose research topics based on the identified gaps, they are required to consult at least ten references for development of their papers (in contrast to the six required references in last year's assignment). These include recently published articles in journals. Students grade their own papers using a rubric and must justify their grade. The course professor provides an incentive of two bonus points for them to search for pictures related to physiology (e.g., stem cells) and comment on them using current scientific information. Volunteers researched concepts that were discussed in class and posted their findings for their peers to review on the discussion board of the Blackboard course management system (http://www.itap.purdue.edu/tlt/blackboard/index.cfm)

The veterinary medical librarian developed a one-page handout based on the survey results. It contains a table that describes the difference between scholarly and peer-reviewed articles, professional articles, and literature reviews. The table includes the purpose, coverage, review process, and characteristics of each type of publication along with several veterinary examples. She included information on the International Veterinary Information Service (IVIS).

\section{RECOMMENDATIONS}

These survey results contribute to the scarce literature on the information behaviors of veterinary students and practitioners. Based on this survey, the authors recommend the following for educational practice and for further research:

- Increase collaboration between veterinary faculty and librarians. This, together with input from students, can result in research that contributes to design of curricula and course elements or specific assignments that expand the body of knowledge in veterinary information literacy. 
- Identify educational strategies that will influence the information-seeking behaviors of firstsemester veterinary students so that they may use the most efficient methods to find resources for their course work.

- Examine the implications of millennials' ubiquitous use of the internet and cell phone technologies for delivering veterinary information literacy instruction, resources, and services.

- Explore the possibility of collaboration with the American Association of Veterinary Medical Colleges, American Veterinary Medical Association, the International Veterinary Information Service (IVIS), or the Veterinary Information Network (VIN) for delivery of veterinary information literacy instruction, since they are influential sources of veterinary information. It is possible that such collaboration could result in the development of consistent instruction about finding, using, and evaluating veterinary information resources.

- Explore why these veterinary students did not use academic libraries' web sites to the extent that they might. By using these sites, the students would find scholarly resources on their topics in a more efficient way. Understanding the reasons why these students prefer not to use libraries' web sites would have implications for the design and marketing of library-based services and resources.

- Conduct research on the cumulative effect of information literacy instruction by veterinary faculty and librarians. Do senior students who received progressive curriculum-integrated information literacy instruction find, access, and use information effectively for clinical practice and lifelong learning?

- Explore the information needs and behaviors of practicing veterinary professionals. Are veterinary schools teaching the information literacy, critical thinking, and lifelong learning skills that they need to make evidence-based clinical decisions? 
- Investigate the possibilities of social networking tools for information literacy.

- Investigate whether there are differences in information-seeking behaviors in students who have different types of experiences before they became veterinary students, such as those who do or do not have advanced degrees; and who have published scientific articles or not.

\section{CONCLUSION}

This paper reports the results of a survey given to first-year veterinary students at Purdue University. The purpose of the survey was to better understand their past and present information-seeking behaviors. This understanding has the potential to help in the design of curricula and course work to integrate information literacy skills. The survey results indicated that there is a need to explore why undergraduate students preferred to use Google over more specialized resources aggregated on the library website. Further, there is a need to determine transitions in information use behavior as the students mature as professionals. Since there is so little research on the information needs and behaviors of veterinary students and practitioners, there are many possibilities for further research in this area. Examples are research on the cumulative effect of information literacy instruction by veterinary faculty and librarians on the information-seeking behaviors of veterinary students and an exploration of the information needs and behaviors of practicing veterinary professionals. It would be interesting to find out whether veterinary schools are teaching information literacy, and how information literacy impacts veterinary students' and veterinarians' critical thinking, lifelong learning skills, and their ability to make evidence-based clinical decisions. The recommendations outlined above emphasize the importance of collaboration between veterinary faculty and librarians in expanding the body of knowledge in veterinary information literacy within both educational practice and research. 


\section{REFERENCES}

1. Willis NG, Monroe FA, Potworowski JA, Halbert G, Evans BR, Smith JE, Andrews KJ, Spring L, Bradbrook A. Envisioning the future of veterinary medical education: The Association of American Veterinary Medical Colleges Foresight Project, Final Report. J Vet Med Educ 34(1):1-41, 2007. 2. Future directions for veterinary medicine. Can Vet J 30:472-476, 1989.

<http://www.ncbi.nlm.nih.gov/pmc/articles/PMC1681137/pdf/canvetj00559-0018.pdf?tool=pmcentrez>. Accessed 12/13/10.

3. Salisbury SK. Evolution of a teacher: Helping students learn. J Vet Med Educ 35(3):326-330, 2008.

4. May SA. Modern veterinary graduates are outstanding, but can they get better? J Vet Med Educ 35(4):573-580, 2008.

5. Association of College \& Research Libraries. Information Literacy Competency Standards for Higher Education, 2000. <http://www.ala.org/ala/mgrps/divs/acrl/standards/standards.pdf >. Accessed 7/16/10. 6. Cavalieri J. Curriculum integration within the context of veterinary education. J Vet Med Educ 36(4):388-396, 2009.

7. Farber E. College libraries and the teaching/learning process: A 25-year reflection. J Acad Libr 25(3):171-177, 1999.

8. Rader HB. The learning environment- - then, now and later: 30 years of teaching information skills. Ref Serv Rev 27(3):219-24, 1999.

9. Rader HB. A silver anniversary: 25 years of reviewing the literature related to user instruction. Ref Serv Rev 28(3):290-6, 2000.

10. Rader HB. Information literacy 1973-2002: A selected literature review. Libr Trends 51(2):242-59, 2002.

11. Raspa D, Ward D (eds). The collaborative imperative: Librarians and faculty working tougher in the information universe. Chicago: American Library Association, 2000. 
12. Schwartz DG, Blobaum PM, Shipman JP, Markwell LG, Marshall JG. The health sciences librarian in medical education: A vital pathways project task force. J Med Lib Assoc 97(4):280-4, 2009. <http://www.ncbi.nlm.nih.gov/pmc/articles/PMC2759163/>. Accessed 12/13/10.

13. Croft, VF. Animal health libraries, librarians, and librarianship: A bibliography. <https://research.wsulibs.wsu.edu:8443/jspui/bitstream/2376/1469/13/animalhealthlibsblbl012809rev.pdf > Accessed 2/2/2010. Pullman, WA: Washington State University Research Exchange, 2009.

14. McCord SK, Croft VF. The Health Sciences Library as partner in case-based learning exercises: The diagnostic challenges at Washington State University. In: Proceedings of the 5th International Conference of Animal Health Information Specialists, 4-7 July, 2005. Running wild, running free: capturing, harnessing and disseminating knowledge flows in support of animal health. $<$ http://hdl.handle.net/2263/6479> Accessed 2/2/10. Onderstepoort, South Africa: University of Pretoria, Veterinary Science Library, Pretoria, 2006: 151.

15. MacNeil KJ, Algermissen VL, Neill CA. Information management skills for veterinary students. J Vet Med Educ 12(1):25-26, 1985.

16. Pelzer NL, Leysen JM. Library use and information-seeking behavior of veterinary medical students. Bull Med Libr Assoc 76(4):328-333, 1988.

<http://www.ncbi.nlm.nih.gov/pmc/articles/PMC227070/?tool=pubmed>. Accessed 12/13/10.

17. Stoyanova L. [Results and conclusions of a survey of student users of the library of the College of Animal Husbandry and Veterinary Medicine, Stara Zagora, Bulgaria.] Rezultati I izvodia ot edna anketa. Bibliotekar (Sofia) 29(2):9-11, 1982.

18. Pelzer NL, Wiese WH, Leysen JM. Library use and information-seeking behavior of veterinary medical students revisited in the electronic environment. Bull Med Libr Assoc 86(3):346-55, 1998. <http://www.ncbi.nlm.nih.gov/pmc/articles/PMC226381/?tool=pubmed>. Accessed 12/13/10. 
19. Alpi KM, Stringer E, DeVoe RS, \& Stoskopf M. Clinical and research searching on the wild side: Exploring the veterinary literature. J Med Libr Assoc 97(3):169-77, July 2009. <http://www.ncbi.nlm.nih.gov/pmc/articles/PMC2706442/> Accessed 12/13/10.

20. Phalen DN. Evaluation of student abilities to respond to a "real-world" question about an emerging infectious disease. J Vet Med Educ 36(2): 216-9, 2009.

21. Rankin, JA. Problem-based medical education: Effect on library use. Bull Med Libr Assoc 80(1):3643, 1992.

22. Lane EA. Problem-based learning in veterinary education. J Vet Med Educ 35(4):631-6, 2008. > 23. Miller JM. A framework for the multiple roles of librarians in problem-based learning. Med Ref Serv Q 20(3):23-30, 2001.

24. Oker-Blom T. Integration of information skills in problem based curricula. In: Proceedings of the 64h International Federation of Library Associations and Institutions (IFLA) General Conference, Amsterdam, Netherlands, 16-21 August, 1998. <http://ifla.queenslibrary.org/IV/ifla64/142-112e.htm> Accessed 12/21/09.

25. McCord SK, Croft VF. The Health Sciences Library as partner in case-based learning exercises: the diagnostic challenges at Washington State University. In: Proceedings of the 5th International Conference of Animal Health Information Specialists, 4-7 July, 2005. Running wild, running free: capturing, harnessing and disseminating knowledge flows in support of animal health. <http://hdl.handle.net/2263/6479> Accessed 2/2/10. Onderstepoort, South Africa: University of Pretoria, Veterinary Science Library, Pretoria, 2006:151.

26. Dodd L. The impact of problem-based learning on the information behavior and literacy of veterinary medicine students at University College Dublin. J Acad Libr 33(2):206-16, 2007. 
27. Weiner SA, Stephens G, Nour AYM. Encouraging analytic thinking and writing skills to enhance learning in freshmen veterinary medicine students using Wikipedia writing assignments. Manuscript in process.

28. Head AJ, Eisenberg MB. How today's college students use Wikipedia for course-related research. First Monday 15(3), March 1, 2010.

<http://firstmonday.org/htbin/cgiwrap/bin/ojs/index.php/fm/article/viewArticle/2830/2476>. Accessed $7 / 16 / 10$.

29. American Veterinary Medical Association. Accreditation Policies and Procedures of the AVMA Council on Education (COE), revised October 2009. 〈http://www.avma.org/education/cvea/coe_pp.asp>. Accessed 7/16/10.

30. Griffiths JR, Brophy P. Student searching behavior and the Web: Use of academic resources and Google. Libr Trends 53(4):539-554, 2005.

31. Van Scoyoc AM, Cason C. The electronic academic library: Undergraduate research behavior in a library without books. portal: Libr Acad 6(1):47-58, 2006.

32. Kim P, Eng TR, Deering, MJ, Maxfield A. Published criteria for evaluating health related web sites: Review. BMJ 318(7184):647-9, 1999.

33. Sladek RM (compiler and editor). Librarians' tips: Exhaustive literature searching in health, $3^{\text {rd }}$ ed, 2003. <http://www.salus.sa.gov.au/Portals/c7ea0d2d-1004-4039-aea8-f4c703c045ce/litsearchtips.html> Accessed 7/16/10.

34. Livengood SP. An evaluation instrument for Internet web sites. Masters thesis, Kent State University, 1999. < http://www.eric.ed.gov/PDFS/ED413899.pdf> Accessed 12/16/10. 
35. The VeriSign domain name primer. Domain Name IndustryB. 5(2), 2008.

$<$ http://www.verisign.com/domain-name-services/domain-information-center/domain-nameresources/domain-name-primer-march08.pdf> Accessed 12/16/10

36. Millennials: A Portrait of Generation Next. Pew Research Center, 2010.

$<$ http://pewsocialtrends.org/assets/pdf/millennials-confident-connected-open-to-change.pdf $>$. Accessed $7 / 16 / 10$.

37. Anderson, K, May FA. Does the method of instruction matter? An experimental examination of information literacy instruction in the online, blended, and face-to-face classrooms. J Acad Lib 36(6):495-500, 2010.

38. Gruppen LD, Rana GK, Arndt TS. A controlled comparison study of the efficacy of training medical students in evidence-based medicine literature searching skills. Acad Med 80(10):940-4, 2005. 
ACKNOWLEDGEMENT: The authors gratefully acknowledge the contribution of Padmasini Ramji in the preparation of this manuscript.

\section{AUTHOR INFORMATION}

Sharon A. Weiner, EdD, MLS, AHIP is Professor of Library Science and holds the position of W. Wayne Booker Chair in Information Literacy at Purdue University. Her research areas are the organizational and policy aspects of information literacy; and the design and assessment of instruction in information literacy competencies. Purdue University Libraries, 504 West State Street, West Lafayette, IN 47907.

Gretchen Stephens, MLS is Associate Professor of Library Science and holds the position of Veterinary Medical Librarian at Purdue University. Her research areas are the literature of veterinary medicine, especially veterinary grey literature, and veterinary information literacy instruction. Purdue University Libraries VETM, 504 West State Street, West Lafayette, IN 47907-2058.

Abdelfattah Y.M. Nour, DVM, MSC, PhD, is Professor of Veterinary Physiology at Purdue University. His research interests are focused on the evaluation of outcomes of web-based learning and the creation of interactive learning environments that encourage students to construct knowledge of veterinary physiology through engagement in the learning process. Dr. Nour is also interested in the optimal integration of educational technology in the design of courses. School of Veterinary Medicine, Purdue University, 504 West State Street, West Lafayette, IN 47907. 


\section{Appendix 1. Survey Instrument}

\section{PURDUE UNIVERSITY}

\section{SCHOOL OF VETERINARY MEDICINE AND LIBRARIES}

\section{Fall 2009: BMS 81100: Systemic Mammalian Physiology}

\section{Survey of Use of Web Resources for Academic Information Gathering}

Dear Student,

The purpose of this survey is to determine what resources you use to gather information for papers and projects related to your academic work. The Purdue School of Veterinary Medicine and Libraries will use this information in developing course content and improving delivery of its curricula. We plan to submit a paper describing the results of this Wikipedia assignment to the Journal of Veterinary Medical Education.

Thank you for your participation!

Abdelfattah Nour, DVM, MS, Ph.D.

Gretchen Stephens

Sharon Weiner, EdD, MLS, AHIP

\section{SURVEY QUESTIONS:}

\section{Background/Demographic Questions:}


1. Please indicate in which age range your age is:

Under age 22 Age 22-26 Age 26-35 Age 35-50 Over age 50

2. Please indicate your gender: Male Female

3. Please indicate the country in which you were born: born in the U.S.

born in a country other than the U.S. (Please specify country of birth)

4. Please identify the college from which you graduated, year of graduation and degree earned:

\begin{tabular}{|l|l|l|}
\hline College & Year Graduated & Degree Earned \\
\hline & & \\
\hline
\end{tabular}

5. Did you take any physiology courses before this one? _ _ Yes _ _ No

6. If the answer is yes, list the courses (name, course number, \# of credits, college where taken) that you have taken:

\begin{tabular}{|l|l|l|l|}
\hline Course Name & Course Number & \# of Credits & Name of College \\
\hline & & & \\
\hline & & & \\
\hline & & & \\
\hline & & & \\
\hline & & & \\
\hline
\end{tabular}

7. How many presentations have you attended during college or at Purdue that were given by a librarian? 
One $\_$- $2-5 \_$More than five

8. How many times during college or at Purdue have you consulted with a librarian on using information?

One _ 2-5_ More than five

\section{Wikipedia Research and Updating Assignment:}

9. For how many of your course projects in college and at Purdue have you used Wikipedia to find information?

For all projects ___ For most projects ___ For some projects ___ For no projects

10. Have you been enrolled in any course that required you to edit or update Wikipedia?

Yes

No

11. For how many of your course projects in college and at Purdue have you used Google or Google

Scholar to find information?

For all projects ___ For most projects ___ For some projects ___ For no projects

12. For how many of your course projects in college and at Purdue have you used the Libraries web site to find information?

For all projects ___ For most projects ___ For some projects ___ For no projects 
13. What criteria do you use to evaluate the quality of web sites and other information related to veterinary medicine?

14. What strategies do you use to conduct an exhaustive search of the literature to find information related to veterinary medicine?

16. What is a literature review?

17. Of the sources listed below, the most comprehensive source for identifying scholarly articles in peerreviewed journals on veterinary medicine topics is:

A veterinary medicine professor

Wikipedia

CAB Abstracts

Cunningham's textbook

18. List an authoritative source online for veterinary information (other than Wikipedia and Merck Veterinary Manual). Make sure to list the correct URL.

19. Explain why you would recommend the above site.

20. List a source online for veterinary information that you would recommend for a lay person interested in finding veterinary information.

21. Explain why you would recommend the above site.

Thank you for completing this survey! 


\section{Appendix II. Criteria for Exhaustive Literature Searches in Veterinary Medicine.}

The authors developed this document based on one that provided tips from Australian librarians on how to conduct exhaustive literature searches in the area of health so that it would apply to veterinary medicine. $^{31}$

- Identify the journals most likely to publish in the subject area, find out where they are indexed, and search those databases.

- Searching the following databases: CAB Abstracts, PubMed, Web of Science, Agricola, Biological Abstracts, and more specialized ones, such as Wildlife and Ecology Studies Worldwide.

- Use both keywords and subject headings that are appropriate for the particular database, such as the CAB Thesaurus (http://www.cabi.org/cabthesaurus/) or MESH Browser (http://www.nlm.nih.gov/mesh/MBrowser.html) in PubMed, particularly when transferring a search strategy from one database to another.

- Use the above thesauri and the 'scope notes' in MEDLINE (OVID) to find related or broader terms to use as keywords. Brainstorm alternatives for keywords, including synonyms and English/American spellings.

- Use truncation after the last common letter of keywords if the database/ search engine allows it.

- Use search engines, such as Google Scholar, to find references from unpublished sources.

- If you have a highly relevant citation, use the Single Citation Matcher in PubMed to find "related articles."

- When you have found some relevant references, check the subject headings used for indexing those references.

- Search authors' names in Web of Science to find out who has cited them. 
- Use the Evidence-Based Veterinary Medicine Association website (http://www.ebvma.org/) to find literature.

- Once you have identified key authors and papers in the area of interest, undertake author searches on bibliographic databases and the web.

- Search the Internet for an author's web page, $C V$, or biography; a search for an author and institution may also identify publications and research in progress.

- If the topic is related to drugs, check the web site of the company that makes the product.

- Check the lists of references given in the articles you retrieve for other relevant papers.

- Identify conferences in the area of interest; they may have published proceedings.

- Contact others working in a similar area to see if they have reference lists they can share or names of others working in related fields.

- Search online catalogues of major or specialized libraries.

- Search relevant association/society, breed group, or support group web sites or contact them about a condition.

- Write to the authors of key studies and ask if they are aware of any unpublished studies in the area or the names of other researchers for the area.

- Search the web for reports, white papers, or other publications from associations, professional colleges, and corporate bodies dealing with the topic.

- Check news sites for reports of recent clinical trials.

- Set up 'save(d) search(es)' or '(auto)alerts' on relevant databases and journal web sites. from: 
Sladek RM (compiler and editor). Librarians' Tips: Exhaustive Literature Searching In Health, $3^{\text {rd }}$ ed, 2003. Retrieved from <http://www.salus.sa.gov.au/Portals/c7ea0d2d-1004-4039-aea8-

f4c703c045ce/litsearchtips.html>. Accessed 7/16/10. 
Appendix III. Online Resources other than Wikipedia and Merck Veterinary Manual with

Justification for their Inclusion, compiled from student survey responses by Gretchen Stephens and Abdelfattah Y. M. Nour.

\begin{tabular}{|c|c|}
\hline Source name (URL) & Librarian evaluation of source \\
\hline $\begin{array}{l}\text { Veterinary Information Network (VIN) } \\
\text { (http://www.vin.com) }\end{array}$ & $\begin{array}{l}\text { An online veterinary destination "for } \\
\text { veterinarians, by veterinarians" providing } \\
\text { databases, message boards, online proceedings, } \\
\text { etc. }\end{array}$ \\
\hline $\begin{array}{l}\text { American Veterinary Medical Association } \\
\text { (AVMA) web site (http://www.avma.org) }\end{array}$ & Leading veterinary association (US) web site \\
\hline $\begin{array}{l}\text { Saunders Comparative Veterinary } \\
\text { Dictionary (available through veterinary } \\
\text { library web page) }\end{array}$ & $\begin{array}{l}2 \text { provided link to vet library web page; none } \\
\text { provided link to actual dictionary }\end{array}$ \\
\hline $\begin{array}{l}\text { Journal of the American Veterinary } \\
\text { Medical Association } \\
\text { (http://www.javma.org) }\end{array}$ & A major professional journal (US) \\
\hline PubMed (http://www.pubmed.com) & $\begin{array}{l}\text { Major online medical database from National } \\
\text { Library of Medicine [indexes } \sim 90 \text { vet journals] }\end{array}$ \\
\hline $\begin{array}{l}\text { University of Minnesota College of } \\
\text { Veterinary Medicine veterinary anatomy } \\
\text { web site (http://vanat.cvm.umn.edu) }\end{array}$ & Veterinary anatomy information from UMCVM \\
\hline $\begin{array}{l}\text { DVM Newsmagazine, Veterinary } \\
\text { Medicine, Veterinary Economics }\end{array}$ & $\begin{array}{l}\text { Publisher web site for the journals indicated and } \\
\text { other products }\end{array}$ \\
\hline
\end{tabular}




\begin{tabular}{|c|c|}
\hline tp://www.dvm360.com/) & \\
\hline $\begin{array}{l}\text { Purdue University Libraries } \\
\text { (http://www.lib.purdue.edu) }\end{array}$ & Local university web site \\
\hline $\begin{array}{l}\text { University of California-Davis Veterinary } \\
\text { Medical School } \\
\text { (http://www.vetmed.ucdavis.edu) }\end{array}$ & Veterinary university web site \\
\hline Veterinary university websites & No specific links provided \\
\hline $\begin{array}{l}\text { Veterinary Clinics of North America: } \\
\text { Equine Practice } \\
\text { (http://www.sciencedirect.com/science/jour } \\
\text { nal/07490739) }\end{array}$ & $\begin{array}{l}\text { Direct link to a veterinary review journal that the } \\
\text { library licenses for university-wide access. }\end{array}$ \\
\hline $\begin{array}{l}\text { American Animal Hospital Association } \\
\text { (http://www.aahanet.com/) }\end{array}$ & A major professional association (US) web site \\
\hline $\begin{array}{l}\text { CAB Abstracts } \\
\text { (http://www2.lib.purdue.edu:5733/spb/ovid } \\
\text { web.cgi) }\end{array}$ & Major world-wide veterinary database \\
\hline $\begin{array}{l}\text { Drs. Foster and Smith's Pet Education web } \\
\text { site (http://www.peteducation.com) }\end{array}$ & $\begin{array}{l}\text { Commercial web site providing online pet } \\
\text { information and animal care tips }\end{array}$ \\
\hline $\begin{array}{l}\text { Fort Dodge Saud Animal web page for } \\
\text { Bronchi-Shield III [drug] } \\
\text { (http://www.bronchi.com.br/download/arqu } \\
\text { ivos.pdf/D-Canine-Infectious(3).pdf) }\end{array}$ & $\begin{array}{l}\text { Brazilian drug web site - provides information } \\
\text { on Infectious Tracheobronquitis in dogs from } \\
\text { Tilley's } 5 \text { Minute Veterinary Consult: Canine } \\
\text { and Feline (no publication date)] }\end{array}$ \\
\hline Merck Manual & No link and title provided: given context assume \\
\hline
\end{tabular}




\begin{tabular}{|c|c|}
\hline & it is the Merck Veterinary Manual \\
\hline $\begin{array}{l}\text { Slatter's Textbook of Small Animal } \\
\text { Surgery, } 3^{\text {rd }} \text { ed. [Elsevier, 2002] } \\
\text { (http://books.google.com/books?id=B_nh6 } \\
\underline{\text { zSr4wUC\&pg=PA707\&dq=small+animal+ }} \\
\underline{\text { surgery\&ei=u6PCSvb6BqXCywS4uqD4A }} \\
\text { w\#v=onepage\&q=\&f=false) }\end{array}$ & $\begin{array}{l}\text { Preview pages from textbook available though } \\
\text { Google Books [preview limit appears to be } \sim 20 \\
\text { pages from anywhere in the title] }\end{array}$ \\
\hline $\begin{array}{l}\text { University of Minnesota College of } \\
\text { Veterinary Medicine web site } \\
\text { (http://www.cvm.umn.edu) }\end{array}$ & Veterinary university web site \\
\hline
\end{tabular}

